\title{
The National Board of Zakat Republic of Indonesia Strategy in Managing the Zakat Potential in Agricultural Sector
}

\section{Ika Yulita, Nurwahidin \& Fahruroji}

Universitas Indonesia

\section{Muhammad Zilal Hamzah}

Universitas Trisakti

Paper to be presented at the $4^{\text {th }}$ International Conference of Zakat (ICONZ)

7-8 October 2020, Surabaya, Indonesia

\begin{abstract}
Zakat as one of the pillars of Islam occupies a very basic and fundamental position, hence His Messenger has ordered Muslims to believe and pay zakat as a form of obedience and the continuation of a harmonious life. Based on agricultural statistics for the period 2015-2019, the agricultural is still as the most important sector in supporting national economic development and it is the sector where most of the Indonesian population works as farmers. The Indonesian people who depend on the agricultural sector are around 38.70 million people, or the equivalent of 30.46\% of the total population in Indonesia. On the other hand, so far, zakat collection has still focused on zakat on assets, income and zakat fitrah, and has not yet touched the agricultural sector massively. Meanwhile, it is known that the potential for zakat in the agricultural sector is very large and until 2018 it is estimated at IDR64.61 trillion. Based on the above, this study seeks to examine how Baznas' strategy is to manage the potential of zakat in the agricultural sector so that it can lead to economic growth in the community, especially agricultural communities in Indonesia.

The results show that there are several strategies implemented by Baznas in managing agricultural zakat and these have been implemented in various forms of programs such as: (i). The system for cultivating agricultural land and providing superior seeds based on zakat; (ii). Agricultural assistance program; (iii). Mustahik move to muzaki (Green Horti) Program; and (iv). Expedition of zakat and economic empowerment program. Another finding is that zakat institutions are still not maximal in conducting socialization and assistance, as well as empowering rural communities. Baznas must start optimizing the collection of agricultural zakat and need to improve performance in making innovative programs that cover all regions in Indonesia.
\end{abstract}

Keywords: Zakat, Agricultural Sector, Baznas Strategy

JEL: Q14; H31

\section{INTRODUCTION}

Zakat, in terms of language (etymology), means sacred, growing, developing, full of blessings (Hafiduddin, 2003). This is as stated in the Qur'an: "And whatever you give for interest to increase within the wealth of people will not increase with
Allah. But what you give in zakah, desiring the countenance of Allah - those are the multipliers." (QS. Ar-Rum: 39). Zakat is one of the pillars of Islam, occupies a very basic and fundamental position. The fundamentals of zakat refer to sharia and provisions, especially in terms of the obligation to pay zakat, the amount of 
zakat calculation issued, and the party was receiving it (BAZNAS, 2019). The practice of collecting zakat in agriculture has also been global, such as in Malaysia (Ab Rahman, et, al. 2020; Rahman, et al., 2014), Bangladesh (Mahmud, Hassan, Alam, Sohag, \& Rafiq, 2014), Pakistan (Suhaib, 2009), Nigeria ((Wali, 2013) and several other countries. Allah SWT and His Messenger have ordered Muslims to believe in and practice zakat to obey Muslims, as Allah says: "And establish prayer and give zakah, and whatever good you put forward for yourselves - you will find it with Allah. Indeed, Allah of what you do, is Seeing." (QS. Al-Baqarah: 110)

The discussion of zakat is closely related to the socio-economic problems of the ummah, because apart from being one of the pillars of Islam and part of worship, zakat also plays a role as a source of finance in Islam which is very important in alleviating poverty and social inequality of the ummah. As in the word of Allah SWT in the al-Qur'an: Zakah expenditures are only for the poor and for the needy and for those employed to collect [zakah] and for bringing hearts together [for Islam] and for freeing captives [or slaves] and for those in debt and for the cause of Allah and for the [stranded] traveler - an obligation [imposed] by Allah. And Allah is Knowing and Wise. (QS. At Taubah: 60)

To create justice and welfare for the people, zakat can be used as an instrument to distribute wealth to those who cannot afford it so that the problem of poverty and inequality in income distribution can be resolved. As stated by Beik (2009) and Adebalki (2013) in Rarasati and Dewanti (2018); Ayuniyyah, Pramanik, Saad, and Ariffin (2018); MaIdraung (2020) found that zakat can reduce poverty levels. Rarasati and Dewanti (2018) found that agricultural zakat can reduce inequality and lead to a more even distribution of farmers income after the implementation of agricultural zakat. This shows that zakat is a very relevant solution in reducing poverty and social inequality in the current phenomenon. The same findings in several studies in other countries have also been proven by Wali (2013); Hassan and Ashraf (2010); Nadzri, Rahman, and Omar (2012); and (Malik, 2016).

Conditions and Potential of Zakat in the Agricultural Sector in Indonesia

Agriculture is one of the supporting sectors for the Indonesian economy. Indonesia, as an agricultural country, makes most of its population make a living as farmers. According to the Central Statistics Agency/BPS (2018), the Indonesian people depend on the agricultural sector as many as 38.70 million people or $30.46 \%$ of Indonesia's population. Meanwhile, zakat collection has so far still focused on zakat on assets, income, and zakat fitrah, not yet touching the agricultural sector. It is necessary to optimize zakat collection in the agricultural sector to contribute to poverty alleviation. Zakat in the agricultural sector in Indonesia has been running as in the following studies, such as: Nopiardo, et, al (2018), who studied the implementation of agricultural zakat on onion farmers in Nagari, Danau Kembar sub-district, Solok Regency; Machfiroh, et, al. (2019), who studied agricultural zakat in Pelihari subdistrict, Tanah Laut Regency.

Based on the PUSKAS BAZNAS report (2019) on year 2018 agricultural statistics (Agriculture Ministry, 2019) in the 2015-2019 period, the agricultural sector is still the most important sector in supporting national economic development. Compared to 2017, in 2018 the agricultural sector of GDP grew by $3.7 \%$, higher than the target of $3.5 \%$. Based on data from the BPS, in 2014, the agricultural sector GDP was IDR1,409.7 trillion, increasing to IDR1,900.3 trillion in 2018. The following is the GDP data for the agricultural sector based on current prices: 
Table 1. Top Agricultural Sector Gross Domestic Product Basic Price Applies (in Trillion IDR)

\begin{tabular}{|c|c|c|c|c|c|c|}
\hline No & Subsector & 2014 & 2015 & 2016 & 2017 & 2018 \\
\hline 1 & Crops & 343,3 & 343,3 & 425,2 & 438,9 & 449,8 \\
\hline 2 & Horticultural Plants & 160,6 & 174,5 & 187,4 & 197,3 & 218,7 \\
\hline 3 & Plantation crops & 398,3 & 405,3 & 428,8 & 471,3 & 489,2 \\
\hline 4 & Ranch & 167,0 & 184,2 & 201,1 & 213,3 & 231,7 \\
\hline 5 & Agricultural\&hunting services & 231,7 & 231,7 & 24,4 & 26,0 & 27,6 \\
\hline 6 & Forestry & 74,6 & 82,3 & 87,5 & 91,6 & 97,3 \\
\hline 7 & Fishery & 245,5 & 288,9 & 317,2 & 348,9 & 385,9 \\
\hline \multicolumn{2}{|r|}{ Total } & $1.409,7$ & $1.555,2$ & $1.671,6$ & $1.787,3$ & $1.900,3$ \\
\hline
\end{tabular}

Source: Estimates from Bank Indonesia data (2019)

The following Table 2 shows that the potential value of zakat on agriculture based on each sub-sector as a whole in 2018 is IDR64.61 trillion. From year to year, the estimated potential for agricultural zakat will continue to increase. In the agricultural sector GDP group issued by BPS, there are agriculture and hunting subsectors, which include: (i).
Agricultural service activities carried out to support agricultural activities (food crops, horticulture, plantations, and animal husbandry) such as rental of agricultural equipment and tractors, and (ii). Hunting and catching wild animals (BAZNAS, 2019). Table 2 shows the portion of the potential zakat potential in the agricultural sector to the total agricultural sector.

Table 2.The Potential for Zakat in the Agricultural Sector (IDR Trillion)

\begin{tabular}{|c|c|c|c|c|c|c|}
\hline No & Subsector & 2014 & 2015 & 2016 & 2017 & 2018 \\
\hline 1 & Crops & 11,67 & 13,51 & 14,46 & 14,92 & 15,29 \\
\hline 2 & Horticultural Plants & 5,46 & 5,93 & 6,37 & 6,71 & 7,44 \\
\hline 3 & Plantation crops & 13,54 & 13,78 & 14,58 & 16,02 & 16,63 \\
\hline 4 & Ranch & 5,68 & 6,26 & 6,84 & 7,25 & 7,88 \\
\hline 5 & Agricultural and hunting services & 0,7 & 0,77 & 0,83 & 0,89 & 0,94 \\
\hline 6 & Forestry & 2,54 & 2,8 & 2,98 & 3,11 & 3,31 \\
\hline 7 & Fishery & 8,35 & 9,82 & 10,78 & 11,86 & 13,12 \\
\hline \multicolumn{2}{|r|}{ Total } & 47,93 & 52,88 & 56,83 & 60,77 & 64,61 \\
\hline
\end{tabular}

Source: estimates from Bank Indonesia data (2019)

From table 2, it can be seen that the potential for zakat from 2014 to 2018 continues to increase. It can be seen that the potential portion of zakat in the agricultural sector until 2018 is IDR 64.61 trillion. Based on the data above, it can be concluded that the potential for zakat growth in the agricultural sector continues to have a positive trend, and several agricultural sub-sectors that grow above the growth of the agricultural sector and economic growth imply the potential for zakat in this subsector.

\section{THEORETICAL BACKGROUND}

\section{The Concept of Zakat}

The obligation of zakat has been explicitly stated in the Qur'an. In Islam, zakat is the main and most important source of finance. The state is responsible for collecting and using it properly, and income from zakat should not be mixed with other public finances. Zakat is an Islamic fiscal policy that is different from conventional fiscal policy. In conventional 
fiscal policy, the source of state finance comes from incentives in the tax rate and the tax base amount of economic activity, whereas in the Islamic fiscal policy system, all provisions regarding the amount of zakat issued have been determined based on the instructions of the Prophet sholallahu 'alaihi wassalam (MaIdraung, 2020). The concept of collecting zakat is following the words of Allah SWT in the Qur'an: "Take, [O, Muhammad], from their wealth a charity by which you purify them and cause them increase, and invoke [Allah is blessings] upon them. Indeed, your invocations are reassurance for them. And Allah is Hearing and Knowing." (QS. At-Taubah: 103)

Zakat is divided into two, namely zakat fitrah and zakat maal. Zakat fitrah is zakat that must be issued at the end of the month of Ramadan or before Eid. Zakat fitrah is compulsory for Muslims who are free and meet certain conditions. Meanwhile, zakat maal is zakat that must be issued by a Muslim who has met certain requirements. The assets that must be issued include gold, silver, rikaz goods, and commodities in the agricultural sector, namely food crops, horticulture, plantations, animal husbandry, fisheries, and forest products.

The scholars put forward the meaning of zakat with different editors, but it is the same in essence, namely that zakat is part of the property with certain conditions, which Allah SWT requires to the owner, to be submitted to those entitled to receive it, with certain conditions as well. In Hawi's book, Al-Mawardi defines zakat taking certain assets from certain properties according to certain characteristics, and being given to certain groups. The concept of zakat itself in law no. 23 of 2011, regarding the management of zakat, zakat is an asset that must be issued by every Muslim or business entity to be given to those who have the right in accordance with Islamic law. Zakat is a maaliah ijtima'iyyah worship, which has a strategic and decisive position for the development and welfare of the people (BAZNAS, 2019). According to Qardhawi (2011), the requirements for assets to be categorized as an object of zakat are full property, assets that can develop, reach the nisab, are more than ordinary needs, are free from debt, and pass a year (haul).

As for the groups entitled to receive zakat, there are eight asnaf, this is based on QS. At-Taubah verse 60 are those who are classified as needy, poor, amil zakat, converts, slave servants, people in debt, fisabilillah, and traveler. The distribution of zakat is given based on three group categories. First, the distribution is based on needs. Then zakat funds are distributed to the needy, poor, servants, people in debt, and ibn sabil. Second, a distribution based on empowerment and religious life spirit, then zakat funds are distributed to converts and fi sabilillah. Third, the distribution based on the necessities of life and motivation given to zakat administrators called 'amil.

\section{Agricultural Zakat and Calculation Methods}

The basis for the obligation to pay zakat in the agricultural sector is following QS. AlBaqarah: 267, namely: "O you who have believed, spend from the good things which you have earned and from that which We have produced for you from the earth. And do not aim toward the defective therefrom; spending [from that] while you would not take it [yourself] except with closed eyes. And know that Allah is Free of need and Praiseworthy," and QS. AlAn'am: 141 that is: "And He it is who causes gardens to grow, [both] trellised and un-trellised, and palm trees and crops of different [kinds of] food and olives and pomegranates, similar and dissimilar. Eat of [each of] its fruit when it yields and give its due [zakah] on the day of its harvest. And be not excessive. Indeed, He does not like those who commit excess." 
There are differences of opinion regarding agricultural sector products that must be zoned. Ibn Umar and several Salaf scholars agreed that the agricultural products obliged to pay zakat include four commodities, namely wheat, sya'ir, grapes, and dates. This is following the hadith of the Prophet Muhammad SAW: "From Abu Burdah, that Abu Musa Al-Asy'ari and Mu'adz bin Jabal radhiallahu 'anhuma were sent to Yemen to teach religious matters. The Prophet -peace, and prayer of Allah be upon him- commanded them not to take zakat from agriculture except from four types of crops: hinthah (refined wheat), sya'ir (coarse wheat), dates, and zabib (raisins)"

\section{Jumhur of Ulama extends} agricultural products' scope to four commodities with other crops that have the same Allah (cause of law). Abu Hanifah argues that zakat from agricultural products is in everything that is planted, both hubbub (seeds), tsimar (fruits), and vegetables. Other scholars, such as Imam Malik and Imam Syafi'i argue that zakat is obligatory on all staple foods eaten and stored. Therefore, according to Imam Malik and Imam Syafi'i, staple foods other than wheat, such as corn, rice, and tubers, are obliged to pay zakat. Along with the times, the majority of scholars agree that all commodities in the agricultural sector can be used as objects of zakat after meeting certain conditions. The difference depends on the categorization of these commodities into agricultural or commercial zakat.

Agricultural zakat is issued when it reaches a nishab of 5 wasaq, with a zakat level of $10 \%$ for rainfed irrigation systems and $5 \%$ for irrigation with irrigation systems. Meanwhile, commercial zakat is imposed on commercial efforts that have exceeded the nishab and haul. The object of commercial zakat is calculated from current assets minus short-term liabilities. Nishab for commercial zakat is 20 dinars or 85 grams of pure gold, and the level reaches $2.5 \%$ (BAZNAS, 2019).

\section{1) Zakat on Food Plants}

Food plants are types of plants that contain carbohydrates and protein that humans use as a source of energy (Farmingid, 2017). Food plants are divided into cereal plants, grain crops, and tubers. Types of cereal crops, for example, are rice, corn, and wheat; for grain crops, for example, are soybeans, peanuts, and green beans; and for tuber crops, for example, cassava, sweet potato, and potato. Some of these plants are the staple food in Indonesia. The method of calculating zakat on food crops is 5 and $10 \%$. However, there is a slight difference in the amount of nishab. According to Abu Hanifah and several scholars, there is no nishab on food plants, so the size and minimum yield of food plants are obligatory for zakat (Qardhawi, 2011). This is based on the generality of the Prophet's hadith, namely: "From the Prophet Muhammad sholallahu 'alaihi wassalam. said:" For plants irrigated with rainwater, springs or groundwater, the zakat is one-tenth, while those irrigated with zakat are one-twentieth of the zakat. "

However, the Jumhur of Ulama, consisting of the Sahaba, Tabi'in, and Ulama afterward, argued that the nishab of the food crop was five wasaq. Therefore, if the plants produced are less than five wasaq, then zakat is not obligatory. This is following the hadith of the Prophet Muhammad SAW: "There is no zakat on crops that are less than 5 wasaq." If it has reached the nishab, if it is irrigated by rainwater or a river, then the amount of zakat will be $1 / 10$ or $10 \%$. However, if it is irrigated using a windmill, or animal power or through an irrigation channel, then the zakat will be $1 / 20$ or $5 \%$. This is in accordance with the Hadith of the Prophet Muhammad SAW said: "Plants irrigated with rainwater or springs or tada rainwater are subject to zakat 1/10. 
Whereas plants irrigated at a cost are subject to zakat 1/20".

Zakat for food crops does not wait for haul, so every time the harvest is harvested, the zakat obligation is immediately issued. When the seeds of the plant have hardened and are suitable for harvesting, then zakat is obliged to be paid. The amount of nishab and provisions for agricultural zakat are contained in the Regulation of the Minister of Religion (PMA) No. 52 of 2014. In PMA No. 52 of 2014 Article 14 states that the amount of nishab for agriculture is $653 \mathrm{~kg}$ of unhulled rice with a value to be paid of $10 \%$ for rainfed and 5\% if using irrigation and other treatments. The figure of $653 \mathrm{~kg}$ is a conversion of 5 wasaq, where 1 wasaq is equal to 60 sha, and 1 sha is equal to $2.176 \mathrm{~kg}$, so 5 wasaq is equal to $5 \mathrm{x} 60 \mathrm{x}$ $2.176 \mathrm{~kg}=653 \mathrm{~kg}$ (BAZNAS, 2019).

Zakat on food crops is paid when the harvest is over, and the amount exceeds the nishab, so for example, a farmer produces one tonne of unhulled rice using the irrigation method, then the zakat that must be paid is $50 \mathrm{~kg}$ of unhulled rice. Another example is when a farmer produces 10 tons of unhulled rice and uses a production cost of around IDR $15,000,000$. It is known that the price of grain is around IDR5000 $/ \mathrm{kg}$, so the farmer's income is $\operatorname{Idr} 5000 \times 10,000 \mathrm{~kg}$ or the same as IDR 50,000,000 per harvest. Therefore, the farmer is required to pay zakat of $500 \mathrm{~kg}$ of grain $(10,000 \mathrm{~kg}$ x $5 \%)$ (BAZNAS, 2019).

\section{2) Horticultural Plant Zakat}

Horticultural crops are also part of the object of agricultural zakat. Horticulture is a garden plant. The types of horticultural plants are fruit plants, vegetable plants, biopharmaceutical plants, and ornamental plants. Commodities (wheat, sya'ir, grapes, and dates) and plants that are used as a staple food cannot be calculated the same as those of horticultural crops. Some opinions state that fruit crops (except dry grapes and dates), vegetable crops, biopharmaceuticals, and ornamental plants are categorized as commercial zakat. The nishab of commercial zakat is 85 grams of gold with a $2.5 \%$ level and is paid after reaching the haul. Haul, according to PMA No. 52 of 2014, is a time limit of one hijri year or 12 months of qamariyah ownership of assets for which zakat must be issued (BAZNAS, 2019).

Currently, the value of pure gold reaches IDR 875,000 per gram, so the nishab for commercial zakat is IDR 875,000 or IDR $74,375,000$ per year. The object of zakat is calculated from current assets which have been deducted by shortterm liabilities during haul, so that when the object of zakat has reached the nishab, it is obligatory to pay zakat of $2.5 \%$. Therefore, if a vegetable farmer can produce net assets that have been freed from all obligations of IDR74,375,000 per year, the farmer is obliged to pay zakat of IDR74,375,000 x $2.5 \%$ or IDR $1,859,000$. Imam Abu Hanifah stated that all that grows on the ground must be paid zakat, including horticultural crops (Qardhawi, 2011). This indicates that the method of calculating zakat on horticultural crops is the same as for food plants for staple food. This is in accordance with QS.al-An'am verse 141 . So that many previous scholars argued that what is meant by "give up your rights on the day you reap the results" is agricultural zakat, which is 5 or $10 \%$ and is paid at harvest time. In addition, the verse mentions zaytun and pomegranate, which are categories of horticultural plants. Therefore, if a fruit farmer can produce fruits that are equivalent to 5 wasaq, then the farmer is required to pay a zakat of 5 or $10 \%$ depending on the type of care for his plants at harvest time. This is also in accordance with PMA No. 52/2014 and Hanapi (2014).

According to Hanapi (2014), plants such as vegetables, onions, and the like are included in the calculation of agricultural zakat, which has a certain nishab and 
without haul. The nishab in question is $653 \mathrm{~kg}$ of unhulled rice or the equivalent of IDR 3,265,000 (IDR 5,000 x 653). Therefore, if a farmer can produce $500 \mathrm{~kg}$ of tomatoes at a price per $\mathrm{kg}$ of IDR 10,000 or the total revenue reaches IDR5,000,000, and the production cost reaches
IDR $1,000,000$, then the zakat spent is IDR5,000,000 × $5 \%$ or IDR250,000. At harvest time. The categorization of agricultural zakat and commercial zakat on production plants can be seen in Table 3 .

Table 3. Categorization of Agricultural Zakat and Commercial Zakat on Production Plants

\begin{tabular}{|c|c|c|c|c|}
\hline $\begin{array}{c}\text { Type of } \\
\text { Production Plant }\end{array}$ & Category & 'Illah & Condition & $\begin{array}{c}\text { Type Of Zakat } \\
\text { And Percentage }\end{array}$ \\
\hline \multirow[t]{2}{*}{$\begin{array}{l}\text { not a staple food } \\
\text { and perishable }\end{array}$} & $\begin{array}{l}\text { long term: for example } \\
\text { coconut, oil palm, } \\
\text { rubber, cocoa and } \\
\text { others. }\end{array}$ & $\begin{array}{l}\text { long lasting or } \\
\text { wealth }\end{array}$ & $\begin{array}{l}\text { Haul and } \\
\text { Nishab }\end{array}$ & $\begin{array}{l}\text { zakat trade at a } \\
\text { rate of } 2.5 \%\end{array}$ \\
\hline & $\begin{array}{l}\text { short term: examples of } \\
\text { onions, ginger and } \\
\text { others }\end{array}$ & $\begin{array}{l}\text { long lasting or } \\
\text { wealth }\end{array}$ & $\begin{array}{l}\text { Haul and } \\
\text { Nishab }\end{array}$ & agricultural zakat \\
\hline \multirow[t]{2}{*}{$\begin{array}{l}\text { not a staple food } \\
\text { and not perishable }\end{array}$} & $\begin{array}{l}\text { Long-term. example of } \\
\text { an orange plantation. }\end{array}$ & Wealth & $\begin{array}{l}\text { Haul and } \\
\text { Nishab }\end{array}$ & $\begin{array}{l}\text { zakat trade at a } \\
\text { rate of } 2.5 \%\end{array}$ \\
\hline & $\begin{array}{l}\text { short-term. examples of } \\
\text { tomatoes, vegetables, } \\
\text { and others }\end{array}$ & Wealth & $\begin{array}{l}\text { Haul and } \\
\text { Nishab }\end{array}$ & agricultural zakat \\
\hline
\end{tabular}

Source: Hanapi, 2014

\section{3) Plantation Zakat}

The plantation is all kinds of activities that cultivate certain plants on soil media or other media in the appropriate ecosystem, starting from marketing them. These plantation crops are among the types of plants with a fairly high selling value, such as oil palm, coffee, cocoa, and tea. Regarding the calculation method, many scholars have made an analogy between plantation zakat and commercial zakat, namely the nishab of 85 grams of gold and a level of $2.5 \%$ and is paid when it reaches the haul. According to Mufraini (2006), the object of zakat on plantations is all the plantation results after being deducted by production costs, garden products consumed by themselves, land rental costs, and costs to meet daily needs. Therefore, if it is known that an oil palm farmer can earn IDR160,000,000 per year with a total cost and other obligations of around IDR95,000,000, then you will get a net asset of IDR65,000,000. The net assets have exceeded the predetermined nishab limit, namely, 85 grams of pure gold or IDR57,205,000 so that the zakat issued is IDR65,000,000 x $2.5 \%$ or IDR1,625,000 per year (BAZNAS, 2019).

\section{4) Livestock Zakat}

Animal husbandry is the activity of breeding and cultivating livestock to get the benefits and results of these activities (Yunus, 2009). The types of livestock in Indonesia are goats, horses, cows, buffaloes, chickens, and other poultry types. According to PMA No. 52 of 2014 Article 16, paragraph 1, zakat on farms is imposed on livestock grazing in public grazing areas and are paid once a year. Zakat on livestock has a certain nishab and level depending on the type of animal. The nishab and zakat levels for farms listed in PMA No. 52/2014 are on camels, cows/buffalo, horses, and goats. Nishab and levels for camels can be seen in Table $4 \mathrm{a}, 4 \mathrm{~b}, 4 \mathrm{c}$ and $4 \mathrm{~d}$. 
Table 4a. Zakat and Nishab Camels

\begin{tabular}{|c|c|}
\hline Number (tail) & Zakat \\
\hline $25-35$ & 1 female camel calf $(>1$ year old $)$ \\
\hline $36-45$ & 2 female camel chicks (> 2 year old) \\
\hline $46-60$ & 3 female camel chicks (> 3 year old) \\
\hline $61-75$ & 4 female camel chicks (> 4 year old $)$ \\
\hline $76-90$ & 2 female camel chicks (> 2 year old) \\
\hline $91-120$ & 2 female camel chicks ( $>3$ year old) \\
\hline $121-129$ & 3 female camel chicks (> 2 year old) \\
\hline $130-139$ & 1 female camel calf ( $>3$ year old) and 1 female camel calf ( $>2$ year old) \\
\hline $150-159$ & 3 female camel chicks (> 3 year old) \\
\hline $160-169$ & 4 female camel chicks (> 2 year old) \\
\hline $170-179$ & 3 female camel chicks (> 2 year old) and 1 female camel calf (> 3 year old) \\
\hline $180-189$ & 2 female camel chicks ( $>2$ year old) and 2 female camel chicks (> 3 year old) \\
\hline 190-199 & 3 female camel chicks ( $>3$ year old) and 1 female camel calf ( $>2$ year old) \\
\hline $200-209$ & 4 female camel chicks $(>3$ year old) and 5 female camel chicks (> 2 year old) \\
\hline
\end{tabular}

Source: PMA No 52 of 2014

Table 4b. Zakat and Nishab Cows

\begin{tabular}{ll}
\hline Number (tail) & Zakat \\
\hline $30-59$ & 1 female calf \\
\hline $60-69$ & 2 male calves \\
\hline $70-79$ & 1 female calf and 1 male calves \\
\hline $80-89$ & 3 male calves \\
\hline $90-99$ & 2 female calves \\
\hline $110-119$ & 2 female calves and 1 male calf \\
\hline$>120$ & 3 female calves and 3 male calves \\
\hline
\end{tabular}

Source: PMA No 52 of 2014

Table 4c. Goat Zakat and Nishab

\begin{tabular}{ll}
\hline Number (tail) & Zakat \\
\hline $40-120$ & 1 goat (2 years) or sheep (1 year) \\
\hline $121-200$ & 2 goats or sheep \\
\hline $201-300$ & 3 goats or sheep \\
\hline
\end{tabular}

Source: PMA No 52 of 2014

Table 4d. Zakat and Nishab Horses

\begin{tabular}{ll}
\hline Number (tail) & Zakat \\
\hline $30-59$ & 1 female foal \\
\hline $60-69$ & 2 stallions \\
\hline $70-79$ & 1 female foal 1 male foal \\
\hline $80-89$ & 2 female foals \\
\hline $90-99$ & 3 male foals \\
\hline $110-119$ & 2 female foals and 1 male foal \\
\hline$>120$ & 3 female foals and 3 male foals \\
\hline
\end{tabular}

Source: PMA No 52 of 2014 
For goats, starting from 400, the zakat is counted every 100 zakat one goat or sheep of the age as mentioned above, and so on, so that 500-599 zakat is calculated for five goats and so on (BAZNAS, 2019). This is following the hadith of the Prophet Muhammad sholallahu 'alaihi wassalam, namely:

"Regarding zakat of goats being
shepherded, if there are 40 to 120
heads, the zakat is one goat, if it is
more than 200, the zakat is two
goats, if more than 200 to 300 zakat
is three goats if more than 300 , then
each for every 100 zakat, one goat."
(HR. Ahmad No.18554, Bukhari, No.
1362 and Nasai, No. 2412).

According to PMA No. 52 of 2014 Article 16, paragraph 2, livestock kept in pens is categorized as commercial zakat. The provisions for commercial zakat (BAZNAS, 2019) are: (i). The period passes for one year; (ii). Reach nishab of 85 grams of gold; (iii). Free from debt; (iii). The level of zakat issued is $2.5 \%$; (iv). Can be paid in cash or in-kind; and (v). The object of zakat is calculated from the value of current assets short-term liabilities. Therefore, if it is known that the total revenue from the goat farming business reaches IDR500,000,000 with production costs such as animal feed, pet care, and other obligations of IDR $360,000,000$ per year, so that the total net assets reach IDR 140,000,000 per year. The goat farmer's net assets have exceeded the stipulated nishab (nishab of gold zakat), so the zakat that must be paid reaches IDR $140,000,000 \times 2.5 \%$ or reaches IDR3,500,000 (BAZNAS, 2019).

\section{5) Zakat on Fisheries}

The fisheries sector in Indonesia is divide into two types, namely aquaculture and capture fisheries. Aquaculture is a form of breeding of aquatic organisms, such as shrimp, shellfish, and marine plants, such as seaweed. Aquaculture has several subsectors, namely marine cultivation, ponds, ponds, cages, floating nets, live nets, and rice fields. Capture fisheries are an effort to catch fish and other aquatic organisms in the wild (seas, rivers, lakes, and other water bodies).

The provisions of zakat on aquaculture and capture fisheries are almost similar to zakat for commerce. This is following PMA No. 52/2014 Article 19. Nishab zakat on fisheries is zakat gold, which is 85 grams of gold with a $2.5 \%$ grade. According to PMA No. 52/2014 Article 20, fishery zakat is the issue at harvest time regarding the fulfillment timing. Therefore, if someone can produce tiger prawns per hectare with a gross income of IDR1,100,000,000 and a cost of IDR430,000,000, that person is immediately subject to $5 \%$ agricultural zakat exceeded the nishab for commercial zakat of IDR57,205,000. The zakat issued is (IDR1,100,000,000 - IDR430,000,000) x $2.5 \%$ or IDR $16,750,000$.

\section{6) Forestry Zakat}

Forestry commodities include gharu wood, resin, rattan, bamboo, pine, teak, and honey. Some opinions categorizing forestry commodities such as timber and non-timber is also the same as commercial zakat. The provisions are the same as previously explained, namely issued after the zakat object reaches nishab with a $2.5 \%$ level and has reached haul. The nishab follows the zakat on gold, which is 85 grams of gold, and the object of zakat includes current assets minus short-term liabilities. However, according to PMA No. 52 of 2014 Article 14, forestry zakat is categorized as agricultural zakat, provided that the nishab is $653 \mathrm{~kg}$ of grain, and the zakat level is 5 or $10 \%$. According to PMA No. 52/2014 Article 15, forestry zakat is pay when the harvest takes place (BAZNAS, 2019). 


\section{RESEARCH METHODOLOGY}

In this study, a qualitative descriptive method is used. This method is a research method which able to obtain an overview of the current situation and as a means of making decisions for the future. This approach research also can answer the research problems that require understanding in depth and thoroughly regarding the object of the study. The data library collection instrument is a tool that selected and used by researchers in carrying out their activities in order to be systematic and accurate.

\section{BAZNAS STRATEGY IN MANAGING ZAKAT AGRICULTURAL}

The following are some of the strategies implemented by BAZNAS in managing agricultural zakat. This is implemented in the form of several programs, including:

Program system of cultivating agricultural land and providing superior seeds based on zakat (BAZNAS and UGM)

Launched since April 2013, this zakat empowerment focuses on the system of cultivating agricultural land and providing superior seeds. By using zakat funds, the program aims to provide agricultural inputs so that farmers can get more yields, and the profits they get can be greater. In addition to providing input (superior seeds), this program can take the form of a capacity-building program for farmers to increase their production.

\section{Agricultural Assistance Program by LAZ}

The program, which has been running since 2014, is in the form of providing assistance aimed at managing farmers rice fields. The assistance provided is in the form of capital at the beginning of the planting season, as well as guidance and education on agricultural zakat among farmers. This empowerment program is expected to help farmers improve their welfare and an effort to return the village to its "khittah" as a source of food for Indonesia. Several years earlier, one of the LAZs in South Sumatra assisted in revolving aid funds to farmers in Telang Sari Village, Jalur 17, Banyuasin. During the two years of the program, the assistance succeeded in changing the behavior of farmers who were often caught in bonded bonds at the beginning of the planting period and paid zakat for agriculture when the harvest season arrived.

\section{The Mustahik Move to Muzaki (Green Horti) Program}

The program above has been carried out by one of LAZ in the form of collaboration in helping farmers in the form of: (i) providing agricultural capital assistance (agricultural inputs such as fertilizers, superior seeds, organic pesticides, plastic hoods, green houses); (ii) mentoring; (iii) post-harvest cultivation training program; (iv) marketing assistance to vegetable agents. One example that has benefited is the Sumber Jaya Tani Association in Sindangjaya Village, Cipanas, Cianjur. Through this program, there is a village assistant who helps farmers build and empower agriculture. Farmers are given training in organic vegetable cultivation, post-harvest training, packaging as well as marketing. Likewise, when farmers encounter ideas or obstacles, they are discussed and looked for solutions together.

Penetrate large supermarkets, peasant associations develop organic agricultural products and are supported by modern packaging, improving hygiene quality to improve the best quality of vegetables and increase economic competitiveness. Payment constraints (farmers require cash payments to be returned as their capital and daily life) are trying to overcome. For the sake of the association sustainability, the farmers 
make an obligatory fee of IDR 500,000 every 4 (four) months, which can be paid in installments. In addition, there is also a voluntary fee starting from IDR10,000 per month, which will be used as capital to buy superior seeds or for other puIdroses.

Program Expedition of zakat and economic empowerment (KEIN, BAZNAS, and LAZISMU)

In April 2018, the Zakat Expedition and Economic Empowerment Program was launched by KEIN, BAZNAS, and LAZISMU in Maluku. This program aims to improve and empower people, especially farmers and fishers, and overcome society's economic inequality. This program was designed to answer various problems that occur in Maluku province in health, education, basic infrastructure, and economic empowerment, especially for fishermen and farmers. In its implementation, the program also empowers farmers and fishermen in the form of assistance, education, and access to capital. It is hoped that the capacity of human resources (HR), business management, and production quality of farmers and fishers can increase.

\section{CONCLUSION}

Based on the explanation above, it can be concluded that, as an agricultural country, Indonesia has enormous potential in collecting zakat in the agricultural sector. However, in its implementation, there are still many obstacles. Among them, the low level of knowledge and understanding of the community about agricultural zakat is motivated by the low level of education and access to information in rural areas, so it is necessary to increase community literacy, especially for farmers in Indonesia. Then the less optimal zakat institutions in conducting socialization and assistance and empowering communities in rural areas. Therefore, BAZNAS must start optimizing agricultural zakat collecting and needs to make improvements in performance in making innovative programs that cover all regions in Indonesia.

\section{REFERENCES}

BPS. (2018). Pertumbuhan Ekonomi Triwulan II-2018. Retrieved from BPS

Ab Rahman, M. F., Ab Rahman, A., \& Ab Rahim, S. F. (2020). Agricultural Zakat From The Islamic Perspective. Journal of Fatwa Management and Research, 92-118.

Ayuniyyah, Q., Pramanik, A. H., Saad, N. M., \& Ariffin, M. I. (2018). Zakat for Poverty Alleviation And Income Inequality Reduction. Journal of Islamic Monetary Economics and Finance, 4(1), 85-100.

BAZNAS, P. (2019). Zakatnomics Sektor Pertanian di Indonesia: PUSKAS BAZNAS.

Bank Indonesia. 2019. Statistik Ekonomi dan Keuangan Indonesia: Januari 2019-Tabel 7.1. [Download 2019 April 24]. Tersedia pada https://www.bi.go.id/id/statistik/ seki/bulanan/Pages/SEKI-JANUARI 2019.aspx

Hafidhuddin D. (2003). Islam Aplikatif. Jakarta: Gema Insani Press.

Hanapi, M. S. (2014). Agricultural zakat accounting in Malaysia. International Journal of Business and Social Science, 5(5).

Mahmud, K.T., Hassan,M.K., Alam, M.F., Sohag, K., and Rofig,F. (2014). Opinion of the zakat recipients on their food security: a case study on Bangladesh. International Journal of Islamic and Middle Eastern Finance and Management, Emerald Group Publishing, vol. 7(3), pages 333-345, August. 
Malik, B. A. (2016). Philanthropy in practice: role of Zakat in the realization of justice and economic growth. International Journal of Zakat, 1(1), 64-77.

Hassan, M. K., \& Ashraf, A. (2010). An integrated poverty alleviation model combining zakat, awqaf and microfinance. Paper presented at the Seventh International ConferenceThe Tawhidic Epistemology: Zakat and Waqf Economy, Bangi, Malaysia.

Kementerian Agama. (2014). Peraturan Menteri Agama Republik Indonesia Nomor 52 Tahun 2014 tentang Syarat dan Tata Cara Penghitungan Zakat Mal dan Zakat Fitri serta Pendayagunaan Zakat untuk Usaha Produktif.

Machfiroh, I. S., Amelia, N., \& Fitriyani, Y. (2019). Potensi zakat pertanian di Kecamatan Pelaihari, Kabupaten Tanah Laut. Proceeding. Paper presented at the of National Conference on Asbis.

MaIdraung, L. W. (2020). Zakat, Islamic Economics And Poverty Alleviation In Indonesia. Proceeding. Paper presented at the International Seminar of Islamic Studies.

Mufraini, M. A. (2006). Akuntansi dan Manajemen Zakat. Jakarta: Prenadamedia Group.

Nadzri, F. A. A., Abd Rahman, R., \& Omar, N. (2012). Zakat and poverty alleviation: Roles of zakat institutions in Malaysia. International Journal of Arts and Commerce, 1(7), 61-72.

Nopiardo, W., Afriani, A., \& Fahlefi, R. (2018). Pelaksanaan Zakat Pertanian (Studi Kasus Petani Bawang di Nagari Kampung Batu Dalam Kecamatan Danau Kembar Kabupaten Solok). Al-Masraf:
Jurnal Lembaga Keuangan dan Perbankan, 3(1), 29-42.

Pertanian, K. (2019). Buku Statistik Makro TW IV 2019. in: Vol. 11 No. 4 (pp. 1): Kementerian Pertanian.

Qardhawi, Y. (2011). Hukum Zakat. Jakarta: Pustaka Litera Antar Nusa.

Rahman, M. F. A., Rahman, A. A., Thaidi, H. A. A., Abdullah, L. H., Anwar, S. M., Bakar, M. F. A., \& Ahmad, U. S. (2014). The Inconsistency of Assessing Agricultural Zakat. Global Journal Al-Thaqafah, 4(1), 17-31.

Rarasati, I., \& Dewanti, D. S. (2018). Poverty Alleviation through Zakat and Income Distribution on Agriculture of Local Commodity, Honey Pinneapple, in Pemalang Regency. Proceeding. Paper presented at the Internasional Conference on Technology, Education and Social Sciences.

Suhaib, A. Q. (2009). Contribution of Zakat in the Social Development of Pakistan. Pakistan Journal of Social Sciences (PJSS), 29(2).

Tanvir Mahmud, K., Kabir Hassan, M., Ferdous Alam, M., Sohag, K., \& Rafiq, F. (2014). Opinion of the zakat recipients on their food security: a case study on Bangladesh. International Journal of Islamic and Middle Eastern Finance and Management, 7(3), 333-345. doi:10.1108/IMEFM-08-2012-0079

Wali, H. N. (2013). Utilization of zakat and Islamic endowment funds for poverty reduction: a case study of Zakat and Hubsi Commission, Kano State-Nigeria. Journal of Economics and Sustainable Development, 4(18), 141-147.

Yunus, R. (2009). Analisis Efisiensi Produksi Usaha Peternakan Ayam Ras Pedaging Pola Kemitraan dan Mandiri Di Kota Palu, Provinsi Sulawesi Tengah. Tesis. Program 
Pasca Sarjana, Universitas

Diponegoro Semarang.

Ika Yulita

Student of Master Program of Science in

Middle East and Islamic Studies,

School of Strategic and Global Studies,

University of Indonesia.

Muhammad Zilal Hamzah

Professor of Public Finance, Faculty of

Economics and Business

Trisakti University

mhd_zilal_hamzah@trisakti.ac.id

Nurwahidin

Lecturer at Master Program of Science in

Middle East and Islamic Studies,

School of Strategic and Global Studies,

University of Indonesia.

Fahruroji

Lecturer at Master Program of Science in

Middle East and Islamic Studies,

School of Strategic and Global Studies,

University of Indonesia. 
